\title{
EFEKTIVITAS PENILAIAN KINERJA DI BADAN KEPEGAWAIAN DAN PENGEMBANGAN SUMBER DAYA MANUSIA (BKPSDM) KABUPATEN ACEH TENGAH
}

\author{
Riza Hasan \\ Akademi Komunitas Negeri Aceh Barat \\ Jalan Sultan Iskandar Muda, Komplek STTU, Ujong Tanoh Darat, Meulaboh, 23617 \\ E-mail: rizahasan@aknacehbarat.ac.id
}

\begin{abstract}
Abstrak - Reformasi birokrasi merupakan upaya untuk mewujudkan tata kelola pemerintahan yang baik (good governance). Tata kelola pemerintahan yang baik salah satunya dapat diketahui dari hasil penilaian kinerja pegawai negeri sipil. Hasil penelitian ini diharapkan dapat memberikan kontribusi kepada instansi pemerintah berkaitan dengan aktivitas penilaian kinerja pegawai negeri sipil. Masalah ini membuat penulis menjadi tertarik untuk mengambil topik mengenai Efektivitas Penilaian Kinerja di Kantor BKPSDM Kabupaten Aceh Tengah. Penelitian ini menggunakan pendekatan kualitatif dengan metode deskriptif field research dengan pendekatan teorisasi induktif. Fokus dalam penelitian ini yaitu mengenai efektivitas penilaian kinerja di BKPSDM Kabupaten Aceh Tengah. Tujuan penelitian ini untuk mendeskripsikan dan menganalisis efektivitas penilaian kinerja dan faktor penghambat penilaian kinerja. Teknik pengumpulan data dilakukan dengan studi kepustakaan, observasi, dokumenter dan wawancara. Kemudian, untuk metode analisis data menggunakan metode analisis interaktif. Dari hasil penelitian dan analisis data, menunjukkan penilaian kinerja di Kantor BKPSDM Kabupaten Aceh Tengah tidak efektif karena sistem penilaian kinerja yang saat ini digunakan tidak sepenuhnya terintegrasi dengan standar kinerja dan indikator kinerja. Faktor penghambat dalam penilaian kinerja tersebut, antara lain: (1) BKPSDM tidak memiliki dokumen analisis jabatan, (2) Penempatan PNS dalam suatu jabatan tidak sepenuhnya memperhatikan pertimbangan antara kebutuhan suatu jabatan dengan kesesuaian latar belakang pendidikan atau kompetensi PNS yang menduduki suatu jabatan, (3) rendahanya controlling atasan kepada bawahannya dalam memberikan penilaian prilaku kerja bawahannya, hal ini menimbulkan penilaian kinerja yang tidak bersifat objektif.
\end{abstract}

Kata kunci: efektivitas penilaian kinerja, sasaran kerja pegawai, prilaku kerja, pegawai negeri sipil.

\begin{abstract}
Bureaucratic reform is an effort to realize good governance. Good governance can be identified in the performance evaluation of the civil servants. Thus, the writer is encouraged conduct a study under the title of "Effectiveness of Performance Appraisal at BKPSDM Office of Aceh Tengah." The findings are expected to contribute to government agencies in term of civil servant's performance appraisal. This qualitative study employed a descriptive field research method with an inductive theoretical approach. The study focused on the effectiveness of performance appraisal at BKPSDM Office of Aceh Tengah. This study aims to describe and analyse the effectiveness of performance appraisal and inhibiting factors of the performance evaluation. The data were collected through literature study, observation, documentaries and interviews. Then, the data were analysed using the interactive analysis method. The findings indicate that the performance evaluation at the BKPSDM Office Aceh Tengah has not been effective. The performance appraisal system currently used is not fully integrated with performance standards and performance indicators. Inhibiting factors in the performance appraisal include (1) missing job analysis document, (2) Mismatch between the needs of an office and educational background or competence of civil servants occupying a position, (3) lack of top-down leadership control from supervisors to the subordinates in providing an in assessing work behaviour of the subordinates. This results in unobjective performance assessments.
\end{abstract}

Keywords: effectiveness of performance appraisal, employee work goals, work behaviour, civil servants.

\section{Pendahuluan}

Implementasi reformasi birokrasi dewasa ini telah memunculkan berbagai tantangan dalam pelaksanaan kinerja lembaga-lembaga pemerintahan dan semakin besarnya permasalahan yang dihadapai oleh negara menimbulkan perubahan dan perbaikan terhadap sistem penyelenggaraan pemerintahan dalam rangka mewujudkan tata kelola pemerintahan yang baik (good governance). Salah satunya tentang landasan hukum dalam penyelenggaraan manajemen Pegawai Negeri Sipil (PNS) 
yang mengalami perubahan yaitu Undang-undang No. 43 Tahun 1999 tentang Pokok-pokok Kepegawaian yang telah digantikan dengan Undang-Undang Nomor 5 Tahun 2014 tentang Aparatur Sipil Negara (ASN).

Didalam Undang-undang ASN pasal 75 dijelaskan penilaian kinerja PNS didasarkan kepada perencanaan kinerja pada tingkat individu dan tingkat unit atau satuan organisasi dengan memperhatikan target, sasaran, hasil, dan manfaat yang dicapai, serta penilaian perilaku dari masing-masing PNS itu sendiri oleh atasannya secara objektif, terukur, akuntabel, partisipatif, dan transparan.

Sebagai tindak lanjut dari pasal 75 Undang-Undang ASN di atas, selanjutnya penilaian kinerja diatur dalam Peraturan Pemerintah No. 46 Tahun 2011 mengenai Penilaian Prestasi Kerja PNS yang pelaksanaannya dijabarkan dalam Peraturan Kepala Badan Kepegawaian Negara Nomor 1 Tahun 2013 tentang Ketentuan Pelaksanaan Peraturan Pemerintah No. 46 Tahun 2011.

Sehubungan dengan penjelasan di atas, selanjutnya sesuai dengan Surat Edaran Menteri Pendayagunaan Aparatur Negara dan Reformasi Birokrasi No. 02 Tahun 2013 ditegaskan bahwa secara efektif, sistem baru penilaian kinerja PNS tersebut berlaku mulai tanggal 1 Januari 2014. Adanya sistem baru dalam penilaian kinerja PNS ini diharapkan mampu memberikan kontribusi kepada instansi pemerintah dalam melakukan penilaian kinerja pegawai.

Penjelasan di atas membuat penulis tertarik untuk mengambil topik mengenai Efektivitas Penilaian Kinerja untuk mengetahui bagaimana Efektivitas Penilaian Kinerja PNS di BKPSDM Kabupaten Aceh Tengah, terlebih mengingat kondisi Pemerintah Kabupaten Aceh Tengah dalam beberapa tahun kebelakang mengalami proses pembenahan karena adanya perubahan kebijakan terkait program reformasi birokrasi yang dilakukan pemerintah pusat dalam rangka mewujudkan tata kelola pemerintah ke arah yang lebih baik lagi (good governance). Apakah Pemerintah Kabupaten Aceh Tengah dapat mengikuti perubahan sistem penilaian kinerja itu dengan baik atau sebaliknya akan menimbulkan permasalahan baru terkait dengan penilaian kinerja.

\section{Rumusan Masalah}

1. Bagaimana efektivitas penilaian kinerja PNS di Kantor Badan Kepegawaian dan Pengembangan Sumber Daya Manusia Kabupaten Aceh Tengah.

2. Faktor-faktor apa saja yang mendorong dan menghambat efektivitas penilaian kinerja PNS di Kantor Badan Kepegawaian dan Pengembangan Sumber Daya Manusia Kabupaten Aceh Tengah.

\section{Tujuan Penelitian}

1. Mengetahui efektivitas penilaian kinerja PNS di Badan Kepegawaian dan Pengembangan Sumber Daya Manusia Kabupaten Aceh Tengah.

2. Mengetahui faktor-faktor apa saja yang mendorong dan menghambat efektivitas penilaian kinerja PNS di Badan Kepegawaian dan Pengembangan Sumber Daya Manusia Kabupaten Aceh Tengah.

\section{Manfaat Penelitian}

Manfaat secara teoritis, memberikan kontribusi terhadap pengembangan ilmu pengetahuan sehingga dapat membandingkan antara teori dan proses pelaksanaan yang ada dilapangan. Dengan demikian, penelitian ini dapat dijadikan sebagai referensi dalam melakukan kajian-kajian dan perbandingan terhadap penelitian selanjutnya.

Manfaat secara praktis, hasil penelitian dapat dijadikan bahan rekomendasi dan evaluasi untuk pemerintah dalam memecahkan masalah yang menjadi penghambat dalam pelaksanaan penilaian kinerja di Badan Kepegawaian dan Pengembangan Sumber Daya Manusia Kabupaten Aceh Tengah.

\section{StUdi PustakA}

\section{Konsep Efektivitas}

Berdasarkan Kamus Besar Bahasa Indonesia, peranan Efektivitas organisasi didefinisikan sebagai tingkat pencapaian organisasi terhadap tujuan jangka pendek maupun jangka panjang berdasarkan nilai-nilai bersaing dari nilai-nilai organisasinya. Di samping itu, Istilah efektif menunjukkan seberapa baik proses dalam memenuhi pencapaian tujuan organisasi (Chatab : 2007:18).

Mardiasmo (2002:132), efektivitas adalah hubungan antara keluaran dengan tujuan atau sasaran yang harus dicapai. Semakin besar kontribusi keluaran yang dihasilkan terhadap nilai pencapaian tersebut, maka dikatakan efektif pula suatu bagian. Pengertian efektivitas tersebut dapat di lihat pada gambar berikut ini:

Gambar 1.

Pengukuran Efektivitas

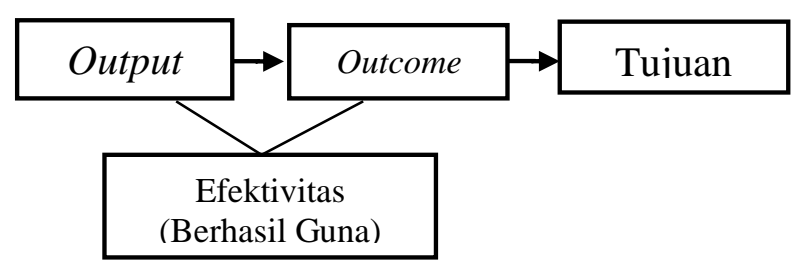

Sumber : Mardiasmo (2002:132).

Berdasarkan penjelasan tersebut, efektivitas merupakan hubungan yang terdapat antara melakukan pekerjaan (Output) dan hasil pekerjaan (outcome) untuk mencapai tujuan. Dengan demikian, efektivitas adalah menggambarkan/ menunjukkan suatu ukuran keberhasilan organisasi dalam usahanya untuk mencapai apa yang menjadi tujuan organisasi.

Keberhasilan organisasi dalam mencapai tujuannya di mulai dari keberhasilan masing-masing pegawainya. Efektivitas suatu organisasi dapat dicapai apabila masingmasing pegawainya dapat mencapai sasaran kerjanya sesuai dengan rencana kerja yang telah ditetapkan oleh organisasi.

\section{Konsep Penilaian Kinerja}

Penilaian kinerja (performance appraisal) dan evaluasi kinerja (performance evaluation) dapat digunakan secara bergantian karena pada dasarnya memiliki arti yang sama (Rivai, 2009:634). Pendapat yang senada juga 
dikemukakan oleh E. Sikulla dalam Mangkunegara (2007:10), bahwa penilaian pegawai merupakan evaluasi yang sistematis dari pekerjaan pegawai dan potensi pegawai yang dapat dikembangkan.

Menurut Wirawan (2009:11), evaluasi kinerja atau penilaian kinerja sebagai proses penilaian yang dilakukan oleh pejabat yang melakukan penilaian dengan cara mengumpulkan informasi mengenai kriteria ternilai atau pegawai yang dinilai. Di samping itu, diperlukan dokumentasi secara formal untuk menilai kinerja ternilai dengan membandingkan dengan standar kinerjanya secara priodik dalam rangka membantu pengambilan keputusan manajemen SDM.

Hal senanada juga dikemukakan oleh Rivai (2004:309), Penilaian kinerja berpedoman kepada pola atau sisitem yang formal dan terstruktur dan digunakan untuk mengetahui, mengukur, menilai serta mempengaruhi sifat yang berkaitan dengan pekerjaan, perilaku maupun hasil kerja, termasuk didalamnya tingkat ketidakhadiran pegawai.

Selanjutnya, Devinisi penilaian kinerja pegawai menurut Peraturan Pemerintah No. 46 tahun 2011 tentang Penilaian Prestasi Kerja Pegawai Negeri Sipil, yaitu suatu proses penilaian secara sistematis atau tersetrukur dan dilakukan oleh pejabat atau atasan penilai terhadap sasaran kerja pegawai dan perilaku kerja PNS sebagai bawahannya.

Berdasarkan devinisi yang dikemukakan oleh para ahli di atas, dapat disimpulkan pengertian kinerja adalah suatu hasil dari pekerjaan yang dicapai oleh masing-masing pegawai atau organisasi dalam melaksanakan tugas dan fungsi pekerjaan berdasarkan ukuran dan waktu yang telah ditentukan guna mewujudkan tujuan organisasi.

\section{Konsep Standar Kinerja}

Standar Kinerja menurut Wirawan (2009:66), adalah tolak ukur minimal kinerja yang harus dicapai karyawan secara individu atau kelompok pada semua indikator kinerjanya. Penyusunan standar kinerja merupakan salah satu bagian dari proses perencanaan strategis organisasi dalam menentukan indikator-indikator yang akan digunakan sebagai alat ukur dalam melaksanakan penilaian kinerja. Oleh karena itu, dalam melakukan penilaian kinerja diperlukan sebuah standar yang disebut dengan standar kinerja. Penilaian kinerja pegawai dilakukan dengan cara membandingkan kinerja yang dinilai dengan standar yang sudah ditetapkan. Berikut ini akan disajikan gambaran tentang proses penyusunan standar kinerja.

Gambar 2.

Proses Penyusunan Standar Kinerja

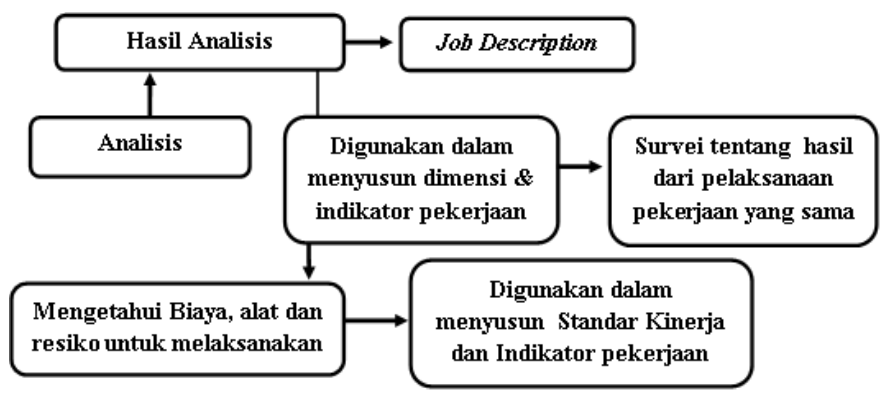

Sumber: Wirawan, (2009:72)
Berdasarkan gambar tentang proses penyusunan standar kinerja tersebut, dapat dijelaskan proses penyusunan standar kinerja dilakukan melalui analisis pekerjaan yang merupakan rumusan indikator-indikator kerja pegawai serta berfungsi menghasilkan Job description. Selanjutnya hasil analisis pekerjaan tersebut juga berfungsi untuk menyusun dimensi dan indikatorindikator kinerja. Indikator kinerja tersebut didefinisikan secara operasional agar dapat memiliki tolak ukur yang jelas untuk nantinya sebagai bahan penilaian terhadap hasil capaian kerja pegawai, disamping itu, langkah selanjutnya melaksanakan pengamatan terhadap masing-masing pegawai dalam melaksanakan dimensi pekerjaannya

\section{Tahapan Penyusunan Standar Kinerja \\ a. Penyusunan Rencana Kerja}

Menurut Wirawan (2009:100), perencanaan kinerja merupakan bagian awal manajemen kinerja karyawan sepanjang tahun. Kinerja karyawan perlu dimanajemeni agar dapat memenuhi harapan organisasi atau perusahaan. Sedangkan menurut Gaol (2014:80), perencanaan sangat penting peranannya baik bagi seseorang, sekelompok orang, organisasi, perusahaan dan sebagainya. Perencanaan adalah proses penentuan langkah-langkah yang hendak dilakukan di masa yang akan. Perencanaan dapat juga dikatakan sebagai proses manajemen pengambilan keputusan di waktu sekarang untuk tujuan di masa yang akan datang.

\section{b. Melakukan Analisis Pekerjaan}

Analisis pekerjaan merupakan prosedur dalam menetapkan maupun membagikan pekerjaan atau tugas dan tuntutan organisasi sesuai keterampilan dari suatu posisi jabatan dan kategori orang yang dibutuhkan yang sesuai dengan kebutuhan pekerjaan tersebut (Dessler, 1997:90). Seseorang ketika direkrut oleh organisasi, seseorang pegawai mempunyai tugas tertentu. Seseorang tersebut harus menjalankan pekerjaan tertentu dan harus melakukan pekerjaan dengan hasil kinerja yang dapat diterima oleh atasan atau organisasinya. Dengan demikian, untuk mengetahui semua hal tersebut, dilakukan analisis pekerjaan terhadap semua jenis pekerjaan yang diperlukan oleh suatu organisasi (Wirawan, 2009:51).

\section{c. Kegunaan Informasi Hasil Analisis Pekerjaan}

Menurut Wirawan (2009:52), manfaat dari hasil analisis pekerjaan berupa informasi mengenai pekerjaan, antara lain:

1) Informasi pekerjaan bermanfaat untuk menyusun uraian pekerjaan (job description) atau deskripsi pekerjaan. Job description diantaranya berisi mengenai daftar fungsi-fungsi pekerjaan, tugas serta tanggung jawab pelaksanaan kegiatan pekerjaan.

2) Informasi dari hasil analisi pekerjaan juga berguna dalam menyusun rangkaian sistem evaluasi kinerja. Dengan demikian, hasil analisis pekerjaan digunakan dalam menyusun tujuan dan rencana kinerja pegawai dalam melaksanakan pekerjaannya.

3) Informasi hasl analisis pekerjaan digunakan untuk menyusun standar kinerja. Dengan informasi hasil analisis pekerjaan yang akurat, standar kinerja dapat 
disusun secara akurat, realiabel, dan dapat di capai oleh karyawan di samping memenuhi harapan organisasi.

4) Informasi dari hasil analisis pekerjaan bermanfaat dalam menyusun dimensi dan indikator instrumen evaluasi kinerja. Di samping itu, digunakan dalam menentukan jenis instrumen yang sesuai dalam menilai kinerja pegawai. Untuk dapat lebih memperjelas kegunaan dari hasil analisis pekerjaan, berikut ini adalah gambaran tentang hubungan antara analisis pekerjaan dengan penilaian kinerja.

Gambar 3.

Hubungan Analisis Pekerjaan dengan Penilaian Kinerja

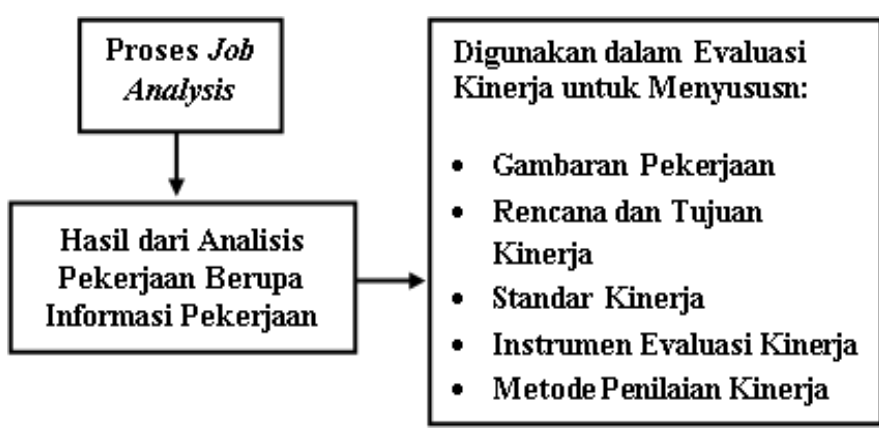

Sumber: Wirawan,(2009:53).

\section{d. Melakukan Job description/ Deskripsi Pekerjaan}

Mathis and Jackson (2006:214), mengemukakan deskripsi kerja adalah proses menyebutkan tugas, tanggung jawab dari suatu pekerjaan. Tugas-tugas harus diketahui dengan jelas apa jenisnya, kemudian tanggung jawab apa saja yang harus dipegang oleh pegawai yang melakukan tugas tersebut, dengan demikian pegawai tidak melakukan kesalahan dengan adanya kejelasan-kejelasan pekerjaan yang harus pegawau lakukan.

Selanjutnya, menurut Mathis dan Jackson (2006:214), ada tiga hal yang menjadi tolak ukur gambaran pekerjaan yang perlu diperhatikan, yaitu:

1) Tugas serta tanggung jawab esensial,

2) Pengetahuan, keterampilan dan kemampuan yang diperlukan,

3) Adanya kerja sama tim dalam menjalankan tugas yang didelegasikan.

\section{e. Menetapkan Standar Kinerja}

Menurut Mahmudi, (2007:41) Standar Kinerja dan Indikator kinerja digunakan sebagai dasar dalam pengukuran kinerja. Setiap organisasi mempunyai tujuan yang jelas, sehingga diperlukan adanya target kinerja untuk dapat mencapai tujuan organisasi. Target tersebut dihubungkan dengan standar dan ukuran (indikator) kinerja. Penetapan standar kinerja bertujuan untuk memberikan nilai terbaik serta praktik terbaik, sedangkan penetapan tolak ukur keberhasilan suatu kinerja adalah untuk menilai ukuran keberhasilan atau kegagalan dalam mencapai tujuan organisasi yang telah ditetapkan.

\section{f. Menetapkan Indikator Kinerja}

Menurut Lohman (2003) dalam Abdullah (2014:145), indikator kinerja yaitu suatu variabel yang digunakan dalam mengekspresikan secara kuantitatif bagaimana efektivitas dan efesiensi proses atau pelaksanaan dengan mengacu pada target dan tujuan organisasi yang ditetapkan.

Selanjutnya, pada perspektif lainnya menurut pendapat Moeherino (2012:108),

1) indikator kinerja yaitu nilai atau karakteristik tertentu yang digunakan untuk mengukur pekerjaan dan hasil dari pekerjaan yang telaha dilakukan dalam suatu kegiatan.

2) Indikator kinerja yaitu tolak ukur yang digunakan dalam menetapkan derajat keberhasilan suatu organisasi dalam rangka mencapai tujuannya

Sehubungan dengan pendapat para ahli di atas berkaitan dengan indikator kinerja dalam melakukan penilaian kinerja PNS, selanjutnya dijelaskan dalam Peraturan Kepala Badan Kepegawaian Negara No 1 Tahun 2013 tentang bagaimana alur sitematika dari proses Pelaksanaan Peraturan Pemerintah Nomor 46 Tahun 2011 Tentang Penilaian Prestasi Kerja Pegawai Negeri Sipil, yaitu:

1) Penilaian prestasi kerja PNS terdiri atas unsur, yaitu Sasaran Kerja Pegawai (SKP) dan Perilaku Kerja.

2) Penilaian Kinerja pegawai dilakukan dengan memberikan penilaian dalam dua model, yaitu penilaian sasaran kerja pegawai (SKP) dan penilaian perilaku kerja pegawai.

3) Bobot nilai dari unsur penilaian SKP yaitu $60 \%$ dan penilaian perilaku kerja yaitu $40 \%$.

Dengan demikian, sasaran kerja pegawai (SKP) dapat diartikan sebagai sebuah bentuk uraian atau gambaran mengenai apa saja kegiatan dan tugas dari masing-masing jabatan dan sasaran kerja yang harus dicapai oleh setiap pegawai dalam menjalankan pekerjaannya. Sedangkan cara melakukan penilaian SKP dilaksanakan dengan cara melakukan perbandingan antara kinerja yang dicapai dengan target atau sasaran kerja yang telah ditentukan.

Selanjutnya, berkaitan dengan sistem atau metode dalam melakukan penilaian Perilaku Kerja sistem penilaiannya dilakukan melalui pengamatan oleh pejabat penilai atau atasan langsung dari pegawai yang akan dinilai sesuai dengan kriteria atau indikator penilaian prilaku kerja yang telah ditetapkan sebelumya.

\section{METODE}

\section{Jenis Penelitian}

Pendekatan penelitian ini menggunakan pendekatan kualitatif dengan metode deskriftif field research dengan pendekatan teorisasi induktif. Pemilihan pendekatan penelitian kualitatif ini sesuai dengan pendapat Bungin (2007:6), penelitian kualitatif merupakan tahapan berpikir kritis ilmiah, yang mana seorang peneliti memulai berpikir secara induktif, yaitu menangkap berbagai fakta atau fenomena-fenomena sosial, melalui pengamatan di lapangan, kemudian menganalisisnya dan kemudian berupaya melakukan teorisasi berdasarkan apa yang diamati itu. 


\section{Lokasi Penelitian}

Penelitian berlokasi di Kantor Badan Kepegawaian dan Pengembangan Sumber Daya Manusia (BKPSDM) Kabupaten Aceh Tengah. Alamat Kantor: Jalan Yos Sudarso No. 1 Takengon Aceh Tengah.

Pemilihan lokasi didasarkan pada fungsi dari Kantor BKPSDM dalam membina dan menjamin terselenggaranya manajamen kepegawaian di Kabupaten Aceh Tengah serta merupakan panutan terhadap instansi-instansi pemerintahan lainnya dalam melaksanakan sistem penilaian kinerja yang efektif. Dengan demikian, BKPSDM Kabupaten Aceh Tengah dituntut untuk dapat meningkatkan kualitas sistem penilaian kinerja organisasinya.

\section{Fokus Penelitian}

a. Efektivitas Penilaian Kinerja PNS di BKPSDM Kabupaten Aceh Tengah berpedoman kepada Peraturan Pemerintah Nomor 46 tahun 2011. Oleh karena itu, sesuai dengan peraturan tersebut, maka fokus penelitian ini, yaitu:

1) Sasaran Kerja Pegawai (SKP)

2) Perilaku kerja pegawai

b. Faktor Pendukung dan Penghambat Penilaian Kinerja PNS Badan Kepegawaian dan Pengembangan Sumber Daya Manusia Kabupaten Aceh Tengah.

Faktor pendukung dan penghambat dapat diketahui melalui analisis terhadap Tahapan Proses Penyusunan Standar Kinerja di Kantor BKPSDM Kabupaten Aceh Tengah, antara lain:

1) Penyusunan Rencana Kerja

2) Melakukan Analisis Pekerjaan dan menyusun Informasi mengenai pekerjaan.

3) Melakukan Pekerjaan sesuai dengan Job description

4) Menetapkan Standar kinerja

5) Menetapkan Indikator Kinerja.

\section{Jenis dan Sumber Data}

a. Data Primer

Data primer adalah data yang diperoleh langsung dari sumber penelitian atau lokasi penelitian, yaitu melakukan wawancara dengan para informan mengenai efektivitas penilaian kinerja di BKPSDM Kabupaten Aceh Tengah.

b. Data Sekunder

Teknik pengumpulan data sekunder dilakukan dengan cara mempelajari, mencatat, dokumen tertulis dan sumber-sumber lain sebagai pendukung proses penelitian yang ada kaitannya dengan masalah penelitian, sehingga dapat dijadikan sebagai bahan analisa permasalahan.

\section{Pemilihan Informan}

Adapun informan dalam penelitian ini adalah pihak terkait yang dianggap memiliki hubungan dengan fokus dari penelitian ini. Informan tersebut adalah sebagai berikut:

a. Sekertaris BKPSDM Kabupaten Aceh Tengah. b. Kepala seksi Penilaian Kinerja \& Kompetensi Jabatan BKPSDM Kabupaten Aceh Tengah.

c. Kepala Sub Bagian Kepegawaian di Bidang Organisasi Sekretariat Pemerintah Daerah Kabupaten Aceh Tengah.

\section{Teknik Pengumpulan Data}

Penelitian ini menggunakan teknik pengumpulan data, yaitu Studi Kepustakaan, observasi, documenter dan wawancara.

\section{Teknik Analisis Data}

Analisis data kualitatif adalah bersifat induktif, yaitu suatu analisis berdasarkan data yang diperoleh, selanjutnya dikembangkan menjadi hipotesis (Sugiyono, 2009:245). Sedangkan "metode yang dipilih untuk menganalisa data adalah metode analisa interaktif yang dimulai dari pengumpulan data, reduksi data, penyajian data, dan penarikan kesimpulan (Miles dan Huberman (1992) dalam Fuad (20014:64)".

Teknik pengolahan data yang digunakan dalam penelitian ini, yaitu bergerak diantara perolehan data, reduksi data, penyajian data dan penarikan kesimpulan/verifikasi. Aritnya data-data yang terdiri dari deskripsi dan uraiannya adalah data yang dikumpulkan, kemudian disusun pengertian dengan pemahaman arti yang berbentuk cerita sitematis, selanjutnya dilakukan usaha untuk menarik kesimpulan dengan verifikasinya berdasarkan semua hal yang terdapat dalam reduksi data dan sajian data.

\section{HaSil dan PEMBAHASAN}

\section{Efektifitas Penilaian Kinerja}

\section{a. Sasaran Kerja Pegawai (SKP)}

Penyusunan SKP (Sasaran Kerja Pegawai) yang dilakukan oleh setiap PNS harus memuat kegiatan tugas jabatan dan ada target yang harus dicapai oleh masingmasing PNS. Setiap kegiatan tugas jabatan yang akan dikerjakan harus berdasarkan pada tugas dan fungsi, wewenang, tanggung jawab dan uraian tugas yang telah ditetapkan. Kegiatan tugas jabatan yang dituangkan ke dalam SKP tersebut harus mengacu kepada rencana kerja tahunan yang telah ditetapkan setiap tahunnya sebagai kegiatan tugas jabatan selama satu tahun.

Pada prinsipnya rencana kerja tahunan yang dijabarkan ke dalam Kegiatan Tugas Jabatan PNS merupakan pembagian pekerjaan yang dibagi habis mulai dari Kepala BKPSDM Kabupaten Aceh Tengah sampai dengan jabatan terendah. Hal tersebut berpedoman kepada Peraturan Kepala BKN Nomor 1 Tahun 2013, bahwa penyusunan SKP dilakukan dari tingkat jabatan tertinggi sampai dengan jabatan terendah dan dijabarkan sesuai dengan tugas dan fungsi.

SKP dan Perilaku Kerja yang telah selesai disusun oleh masing-masing PNS, selanjutnya disetujui dan ditetapkan di awal tahun sebagai Rencana Kerja Tahunan dan di akhir tahun dinilai oleh Pejabat Penilai yaitu atasan langsung dari setiap pegawai yang akan dinilai. Dengan demikian, SKP dan Perilaku Kerja dapat berguna sebagai standar kinerja dan indikator kinerja dalam melaksanakan 
penilaian kinerja sesuai dengan target rencana kerja yang telah ditentukan.

Berdasarkan pelaksanaan penilaian kinerja yang telah dilakukan oleh BKPSDM Kabupaten Aceh Tengah, menunjukkan hasil penilaian kinerja adalah Baik (B). Nilai baik tersebut didasarkan atas penjumlahan dari nilai ratarata setiap pegawai yang ada di Kantor BKPSDM Kabupaten Aceh Tengah. Namun, berdasarkan hasil penelitian yang dilakukan, menunjukkan proses dan mekanisme dalam penyusunan rencana kerja tahunan yang dijabarkan ke dalam SKP tidak sepenuhnya terintegritas dengan standar kinerja. Standar kinerja merupakan tolak ukur dalam melakukan penilaian kinerja dan merupakan salah satu bagian dari perencanaan strategis organisasi dalam menentukan indikator-indikator apa saja yang akan digunakan sebagai alat ukur untuk mengetahui tingkat keberhasilan suatu pekerjaan yang telah ditetapkan sebelumnya.

Salah satu standar kinerja yang tidak dilakukan dan tidak dimiliki oleh Kantor BKPSDM Kabupaten Aceh Tengah adalah Dokumen Analisis Jabatan (ANJAB). ANJAB merupakan hasil dari kegiatan analisis terhadap jenis pekerjaan yang diperlukan dan berisikan gambaran tentang pekerjaan yang nantinya akan dilakukan dalam mencapai tujuan organisasi. Di samping itu, ANJAB juga berfungsi untuk mengetahui jenis kompetensi atau keterampilan apa saja yang dibutuhkan sesuai dengan pekerjaan yang telah ditetapkan sebelumnya. Selanjutnya, membentuk tugas dan fungsi jabatan yang dibutuhkan ke dalam masing-masing bidang atau sub bidang pekerjaan.

\section{b. Perilaku Kerja}

Proses Penilaian Perilaku kerja di Kantor BKPSDM Kabupaten Aceh Tengah dilakukan melalui pengamatan atasan terhadap perilaku bawahannya. Berdasarkan indikator penilaian perilaku kerja yang telah ditetapkan dalam peraturan pemerintah No. 46 Tahun 2011. Penilaian Perilaku Kerja tersebut meliputi aspek: orientasi pelayanan, integritas, komitmen, disiplin, kerjasama, dan kepemimpinan. Penilaian terhadap aspek kepemimpinan hanya dilakukan bagi PNS yang menduduki jabatan struktural.

Selanjutnya, berkaitan dengan hasil penilaian Perilaku Kerja di Kantor BKPSDM Kabupaten Aceh Tengah, tidak menunjukkan adanya permasalahan dalam proses pelaksanaan penilaian prilaku dan telah sesuai dengan ketentuan peraturan yang berlaku serta berjalan secara efektif, hal tersebut terlihat dari hasil penelitian yang dialakukan dan penilaian yang dilakukan oleh Pejabat Penilai terhadap bawahannya telah sesuai dengan aspek-aspek penilaian Perilaku Kerja seperti yang di atur dalam Peraturan Pemerintah No. 46 Tahun 2011.

\section{Faktor Pendorong dan Penghambat Penilaian Kinerja di BKPSDM Kabupaten Aceh Tengah}

Pembahasan hasil penelitian mengenai faktor pendorong dan penghambat penilaian kinerja pegawai akan diuraikan sesuai dengan konsep tahapan pengukuran kinerja, antara lain meliputi rencana kerja, analisis pekerjaan dan informasi pekerjaan, job description, standar pekerjaan (kinerja) dan indikator kinerja.

\section{a. Rencana Kerja}

Hasil penelitian menunjukkan bahwa BKPSDM Kabupaten Aceh Tengah telah melakukan sistem perencanaan kerja, hal ini terlihat dari rencana kerja yang disusun, bahwa penyusunan rencana kerja Kantor BKPSDM merupakan turunan dari rencana strategis Pemerintah Daerah Kabupaten Aceh. Sedangkan penyusunan visi, misi BKPSDM Kabupaten Aceh Tengah mengacu kepada visi, misi Pemerintah Kabupaten Aceh Tengah.

Rencana kerja BKPSDM merupakan penjabaran dari Rencana strategis BKPSDM yang berlaku selama 5 (lima) tahun, selanjutnya rencana kerja diuraikan dan di masukkan ke dalam pekerjaan setiap masing-masing bidang di dalam susunan organisasi BKPSDM Kabupaten Aceh Tengah. Dengan demikian, Rencana kerja tersebut akan menjadi pedoman BKPSDM Kabupaten Aceh Tengah dalam menjalankan roda organisasi pemerintahan.

\section{b. Analisis Pekerjaan}

Pelaksanaan analisis pekerjaan menghasilkan informasi mengenai pekerjaan yang dilakukan oleh setiap PNS. Di samping itu, hasil analisis pekerjaan ini juga berfungsi unuk menyususn job description yaitu berupa uraian/gambaran/rincian pekerjaan yang dijadikan sebagai dasar dalam melaksanakan pekerjaan dan sebagai tolak ukur untuk melakukan penilaian kinerja PNS.

Berkaitan dengan pelaksanaan analisis pekerjaan dan informasi/uraian mengenai pekerjaan, menunjukkan bahwa BKPSDM Kabupaten Aceh Tengah tidak memiliki dokumen analisis pekerjaan (ANJAB) yang berisikan job description. Hal ini terjadi disebabkan karena Kantor BKPSDM tidak memiliki tugas pokok dan fungsi dalam menyusun ANJAB, sedangkan yang memiliki wewenang untuk menyusun dokumen ANJAB adalah Bagian Organisasi Sekretariat Pemerintah Kabupaten Aceh Tengah.

Kesimpulan dalam pembahasan ini, bahwa BKPSDM Kabupaten Aceh Tengah tidak melakukan analisis pekerjaan dan memiliki informasi yang berkaitan dengan uraian pekerjaan. Selama ini, dalam proses penyusunan SKP berkaitan dengan uraian pekerjaan yang dijabarkan ke dalam Sasaran Kerja Pegawai (SKP) tidak dilakukan berdasarkkan analisis pekerjaan (Dokumen ANJAB) sedangkan analisis pekerjaan ini berfungsi unuk menyususn job description yaitu berupa uraian/gambaran pekerjaan yang digunakan sebagai dasar untuk melaksanakan pekerjaan dan sebagai tolak ukur dalam melakukan penilaian kinerja PNS. Ini artinya, hasil Analisis pekerjaan berupa uraian pekerjaan yang digunakan untuk melaksanakan penilaian SKP tidak terhubung dengan sistem penilaian kinerja yang diterapkan oleh Kantor BKPSDM Kabupaten Aceh Tengah.

\section{c. Job Description}

Deskripsi pekerjaan di BKPSDM Kabupaten Aceh Tengah secara sistematis mengacu kepada Peraturan Kabupaten Aceh Tengah Nomor 54 tahun 2016 tentang Susunan Organisasi dan Tata Kerja Badan Kepegawaian dan Pengembangan Sumber Daya Manusia Kabupaten Aceh Tengah. 
Hal yang perlu diperhatikan di dalam mengaplikasikan job description tersebut adalah kesesuaian antara penempatan jabatan pegawai dengan kemampuan/keterampilan dan pengetahuan yang dimiliki oleh pegawai. Berdasarkan hasil penelitian, menunjukkan penempatan PNS dalam suatu jabatan tidak sepenuhnya memperhatikan pertimbangan terhadap latar belakang pendidikan PNS. Di samping itu, kurangnya perhatian tersebut juga dapat di lihat dari struktur organisasi yang menunjukan masih ada beberapa posisi jabatan yang tidak sesuai dengan latar belakang pendidikan PNS dalam mengisi suatu jabatan.

Kesimpulan yang dapat diambil yaitu bahwa $J o b$ description yang dilaksanakan oleh BKPSDM Kabupaten Aceh Tengah dimulai dari tingkat Kepala BKPSDM sampai dengan kepala sub-sub bidang dan kelompok jabatan fungsional. Namun, dalam proses pelaksanaan job description, terkait penempatan posisi jabatan tidak berjalan efektif, masih ditemukan beberapa jabatan yang tidak sesuai dengan pendidikan PNS dalam mengisi suatu jabatan. Hal ini tentunya dapat berpengaruh tehadap kualitas dari hasil suatu pekerjaan.

\section{d. Standar Kinerja}

Hasil penelitian menunjukkan standar kinerja yang digunakan BKPSDM Kabupaten Aceh Tengah dalam melaksanakan penilaian kinerja berpedoman kepada Peraturan Pemerintah No. 46 Tahun 2011 tentang Penilaian Prestasi kerja dan sebagai petunjuk teknis dari Peraturan tersebut, BKPSDM Kabupaten Aceh Tengah menggunakan Peraturan Kepala BKN No. 1 Tahun 2013 tentang Ketentuan Pelaksanaan Peraturan Pemerintah No. 46 Tahun 2011 tentang Penilaian Prestasi kerja PNS. Namun, dalam pelakasanaan penyusunan dan pelaksanaan penilaian SKP tidak merujuk kepada dokumen ANJAB, doukumen ANJAB merupakan hasil dari analisis pekerjaan yang dibutuhkan dan tentang uraian pekerjaan yang akan dilakukan dalam rangka mencapai tujuan organisasi yang telah ditetapkan. Hal ini menyebabkan penilaian kinerja dapat bersifat tidak efektif.

\section{e. Indikator Kinerja}

Tanpa indikator kinerja, sangat sulit untuk menilai efektivitas dari suatu kinerja atau tingkat capaian dari hasil pekerjaan. Oleh karena itu, sesuai dengan Peraturan Pemerintah No. 46 Tahun 2011 tentang Penilaian Prestasi Kerja, adapun indikator kinerja yang digunakan dalam melakukan penilaian kinerja di Kantor BKPSDM, terdiri dari dua jenis, yaitu Sasaran Kerja Pegawai (SKP) dan Perilaku Kerja (PK).

Berdasarkan hasil penelitian, berkaitan dengan proses penilaian prilaku kerja, Pejabat Penilai di Kantor BKPSDM Kabupaten Aceh Tengah mengatakan bahwa tidak terdapat unsur perasaan yang tidak enak apabila tidak memberikan nilai "baik" untuk seluruh bawahannya. Dengan demikian, dapat disimpulkan penilaian kinerja yang dilakukan oleh pimpinan sebagai atasan kepada bawahannya telah sepenuhnya atas dasar kinerja pegawai tidak ada hubungan emosioanl atau perasaan yang dapat menyebabkan penilaian tidak bersifat nyata, artinya penilaian kinerja yang dilakukan sepenuhnya objektif.
Berdasarkan pembahasan mengenai faktor-faktor pendorong dan penghambat dalam penilaian kinerja pegawai, dapat dikelompokkan apa saja yang menjadi faktor penghambat dan faktor pendorong dalam melakukan penilaian kinerja pegawai. Berikut merupakan tabel faktor penghambat dan faktor pendorong dalam penilaian kinerja pegawai :

Tabel: 1:

Faktor Penghambat dan Faktor Pendorong Penilaian Kinerja

\begin{tabular}{|c|c|}
\hline Faktor Pendorong & Faktor Penghambat \\
\hline $\begin{array}{l}\text { BKPSDM Kabupaten } \\
\text { Aceh Tengah telah } \\
\text { melakukan sistem } \\
\text { perencanaan } \\
\text { kerja/kinerja }\end{array}$ & $\begin{array}{l}\text { BKPSDM Kabupaten Aceh } \\
\text { Tengah telah melakuan } \\
\text { perencanaan penilaian kinerja } \\
\text { namun tidak tidak sesuai dengan } \\
\text { mekanisme penyusunan standar } \\
\text { kinerja, yaitu tidak memiliki } \\
\text { analisis pekerjaan, sedangkan } \\
\text { analisis pekerjaan berfungsi } \\
\text { unuk menyususn job description } \\
\text { yaitu berupa uraian/ gambaran/ } \\
\text { rincian pekerjaan yang } \\
\text { digunakan sebagai dasar dalam } \\
\text { melaksanakan pekerjaan dan } \\
\text { sebagai dasar atau tolak ukur } \\
\text { untuk melakukan penilaian } \\
\text { sasaran kerja pegawai. }\end{array}$ \\
\hline $\begin{array}{l}\text { Standar penilaian } \\
\text { kinerja didasarkan } \\
\text { pada PP No } 46 \text { Tahun } \\
2011 \text { tentang Penilaian } \\
\text { Prestasi Kerja dan } \\
\text { Peraturan Kepala BKN } \\
\text { sehingga terdapat } \\
\text { acuan yang jelas dalam } \\
\text { pemberian penilaian } \\
\text { kinerja. }\end{array}$ & $\begin{array}{l}\text { Proses pelaksanaan job } \\
\text { description, terkait penempatan } \\
\text { posisi jabatan belum berjalan } \\
\text { secara efektif, masih ditemukan } \\
\text { beberapa jabatan yang tidak } \\
\text { sesuai dengan latar belakang } \\
\text { pendidikan PNS, tentunya hal ini } \\
\text { harus dipertimbangkan karena } \\
\text { merupakan tolak ukur yang } \\
\text { menjadi standar kemampuan } \\
\text { atau keterampilan seorang } \\
\text { pegawai dalam mengisi suatu } \\
\text { jabatan tertentu. }\end{array}$ \\
\hline
\end{tabular}

\section{KESIMPULAN}

\section{Efektifitas Penilaian Kinerja PNS di BKPSDM Kabupaten Aceh Tengah}

Berdasarkan hasil penilaian kinerja yang dilakukan Kantor BKPSDM Kabupaten Aceh Tengah, menunjukkan hasil nilai kinerja adalah Baik (B). Nilai baik tersebut didasarkan atas penjumlahan hasil rata-rata penilaian kinerja setiap pegawai BKPSDM Kabupaten Aceh Tengah.

Namun, berdasarkan hasil penelitian lebih lanjut, menunjukkan hasil penilaian kinerja Kantor BKPSDM Kabupaten Aceh Tengah tidak sepenuhnya efektif. Hasil penelitian menunjukkan proses dan mekanisme dalam penyusunan rencana kerja tahunan yang dijabarkan ke dalam SKP tidak sepenuhnya terintegritas dengan standar kerja/kinerja, sedangkan standar kinerja merupakan tolak ukur dalam melakukan penilaian kinerja dan merupakan salah satu bagian dari perencanaan strategis organisasi 
dalam menentukan indikator-indikator apa saja yang akan digunakan sebagai tolak ukur dalam menilai tingkat keberhasilan suatu pekerjaan yang telah ditetapkan sebelumnya.

Salah satu standar kinerja yang tidak dilakukan dan tidak dimiliki Kantor BKPSDM Kabupaten Aceh Tengah adalah Dokumen Analisis Jabatan (ANJAB). ANJAB merupakan hasil dari kegiatan analisis terhadap jenis pekerjaan yang diperlukan dan berisikan uraian pekerjaan yang akan dilakukan dalam mencapai tujuan organisasi. Di samping itu, ANJAB juga berfungsi untuk mengetahui jenis kompetensi atau keterampilan apa saja yang dibutuhkan sesuai dengan pekerjaan yang telah ditetapkan sebelumnya.

Dengan demikian, menunjukkan bahwa mekanisme penilaian SKP berkaitan dengan uraian pekerjaan yang dijabarkan ke dalam Sasaran Kerja Pegawai (SKP) tidak dilakukan melalui analisis pekerjaan (Dokumen ANJAB) sedangkan analisis pekerjaan ini berfungsi unuk menyususn job description atau uraian/gambaran pekerjaan dalam melaksanakan pekerjaan dan berfungsi sebagai tolak ukur dalam melakukan penilaian kinerja yang selanjutnya diuraikan di dalam SKP. Ini artinya, hasil analisis pekerjaan berupa uraian pekerjaan yang digunakan untuk menyusun dan melaksankan penilaian SKP tidak terhubung dengan sistem penilaian kinerja yang diterapkan oleh Kantor BKPSDM Kabupaten Aceh Tengah.

Selanjutnya, berkaitan dengan pelaksanaan penilaian Perilaku Kerja, menunjukkan bahwa hasil penilaian telah sesuai dengan ketentuan peraturan yang berlaku dan berjalan secara efektif, hal ini terlihat dari penilaian yang dilakukan oleh Pejabat Penilai (atasan langsungnya) terhadap bawahannya telah sesuai dengan aspek-aspek penilaian Perilaku Kerja seperti yang di atur dalam Peraturan Pemerintah No. 46 Tahun 2011.

Proses dan mekanisme penilaian Perilaku kerja di Kantor BKPP dilakukan melalui pengamatan oleh atasan terhadap prilaku bawahannya. Hasil penilaian Perilaku Kerja di Kantor BKPSDM Kabupaten Aceh Tengah tidak menunjukkan adanya permasalahan dalam proses penilaian prilaku kerja dan telah sesuai dengan ketentuan peraturan yang berlaku serta berjalan dengan efektif, hal tersebut dapat terlihat dari hasil penelitian yang dialakukan dan penilaian yang dilakukan oleh Pejabat Penilai terhadap bawahannya menunjukkan telah sesuai dengan aspekaspek penilaian Perilaku Kerja seperti yang diatur dalam Peraturan Pemerintah No. 46 Tahun 2011.

\section{Faktor Pendorong dan Penghambat Penilaian Kinerja PNS BKPSDM Kabupaten Aceh Tengah}

Pada pelaksanaan penilaian kinerja pegawai terdapat beberapa faktor yang turut serta mendukung jalannya penilaian kinerja pegawai, yaitu : (1) BKPSDM Kabupaten Aceh Tengah telah melakukan sistem perencanaan kerja, namun perencanaan kerja tersebut tidak terhubung dengan standar kinerja lainnya, yaitu tidak melakukan analisis pekerjaan dan job description (2) Standar penilaian kinerja didasarkan pada peraturan pemerintah no. 46 tahun 2011 dan peraturan Kepala BKN sehingga terdapat acuan yang jelas dalam pemberian penilaian.
Selain faktor pendorong, terdapat pula beberapa faktor penghambat jalannya penilaian kinerja pegawai, yaitu : (1) Penempatan PNS dalam suatu jabatan tidak sepenuhnya memperhatikan pertimbangan terhadap latar belakang pendidikan pegawai, hal ini disebabkan karena tidak adanya dokumen ANJAB yang seharusnya dapat dijadikan pedoman dalam menentukan kesesuaian antara pekerjaan dengan kompetensi yang harus dimiliki dalam menduduki suatu jabatan (2) BKPSDM Kabupaten Aceh Tengah tidak memiliki analisis pekerjaan, sedangkan analisis pekerjaan berfungsi unuk menyususn job description yaitu berupa uraian/ gambaran pekerjaan yang digunakan sebagai acuan atau pedoman dalam melakukan pekerjaan dan sebagai tolak ukur untuk melakukan penilaian kinerja pegawai.

\section{REFERENSI}

[1] Agustina, Tri Siwi. 2011. Peranan Inkubator Bisnis Perguruan Tinggi Dalam Meminimalkan Resiko Kegagalan Bagi Wirausaha Baru Pada Tahap Awal (Start-Up). Majalah Ekonomi, 21(1) : 65

[2] Ardana, I Komang. Mujiati, Ni Wayan. Utama, I Wayan Mudiartha, 2012, Manajemen Sumber Daya Manusia, Edisi Pertama, Cetakan Pertama, Graha Ilmu, Yogyakarta.

[3] Bungin,Burhan. 2007, Penelitian Kualitatif: Komunikasi, Ekonomi, kebijakan Publik, dan Ilmu Sosial Lainnya, Edisi Pertama, Cetakan ke-4, Kencana Prenada Media Group, Jakarta.

[4] Chatab,Nevizond. 2007. Profil Budaya Organisasi Bandung :Alfabeta

[5] Dessler, Gary, 1997. Manajemen Sumber Daya Manusia. PT. Prenhallindo: Jakarta

[6] Gaol, Chr. Jimmy L. 2014, A to Z, Human Capital, Manajemen Sumber Daya Manusia, Konsep, Teori, dan Pengembangan dalam Konteks Organisasi Publik dan Bisnis, PT Grasindo Anggota Ikapi, Jakarta.

[7] Mangkunegara, Anwar Prabu. 2005. Evaluasi Kinerja Sumber Daya Manusia, Bandung, Rajawali Pers.

[8] Mahmudi, 2007. Manajemen Kinerja Sektor Publik. Yogyakarta: UPP STIM YKPN.

[9] Mardiasmo. 2002. Akuntansi Keuangan Sektor Publik. Yogyakarta: Andi.

[10] Moeheriono. 2012. Perencanaan, Aplikasi dan Pengembangan Bisnis Publik (Indikator Kinerja Utama), Jakarta: Rajawali Press.

[11] Sugiyono, 2009, Metode Penelitian Kuantitatif dan Kualitatif, Bandung: CV. Alfabeta

[12] Wirawan, 2009. Evaluasi Kinerja Sumber Daya Manusia: Teori, Aplikasi dan Penelitian. Jakarta: Salemba Empat.

[13] Laporan Akuntabilitas Kinerja Instansi Pemerintah (LAKIP) Badan Kepegawaian dan Pengembangan Sumber Daya Manusia Kabupaten Aceh Tengah Tahun 2017.

[14] Undang-Undang Nomor 5 Tahun 2014 tentang Aparatur Sipil Negara (ASN).

[15] Peraturan Pemerintah No 46 Tahun 2011 tentang Penilaian Prestasi Kerja Pegawai Negeri Sipil.

[16] Peraturan Kepala Badan Kepegawaian Negara No 1 Tahun 2013 tentang Ketentuan Pelaksanaan Peraturan Pemerintah No. 46 Tahun 2011. 